\title{
Following the Life Stories of Participants in the 1956 Hungarian Revolution ${ }^{1}$
}

\section{Tibor Valuch}

\begin{abstract}
To date, analyses of the 1956 Revolution have devoted little attention to examining the events pertaining to this period from the aspect of social history. In this study Valuch explores the life stories of those who participated in these events from six decades ago in an attempt to introduce the most important characteristics determining various life phases from before and after the revolution. Based upon life interviews conducted during the 1990s with former 1956 participants living mainly in the city of Debrecen and its surrounding Hajdú-Bihar County, Valuch's examination outlines those experiences determining their socialization, including family background, political attitudes predating the revolution and political activity conducted during 1956 . His focus will then turn to the issue of how these individuals experienced the period of retribution following the revolution as well as attempts by the Kádár regime to marginalize participants in the 1956 Revolution. What general effect did collaboration with the revolutionary movement have on life during the Kádár regime and the political attitudes held by these individuals? In the final section, factors characterizing life stories from the 1956 period will be analyzed.

This is a correction to the original article. For information about the changes made, please see the erratum http://dx.doi.org/10.5195/ahea.2017.272
\end{abstract}

Keywords: 1956 Revolution, political activity, life stories, the Kádár Regime

Biography: Tibor Valuch is a social historian as well as research chair at the Hungarian Academy of Sciences Center for Social Sciences Institute in Political Science. He is also a professor at the Institute of History at Eszterházy Károly University in Eger. His main research fields include the social and cultural history of Hungary after the Second World War. He is author of several papers and monographs, including his latest book, Contemporary Hungarian Society (Budapest Osiris Publisher Ltd, 2015).

From its outbreak in the last two weeks of October 1956 to the period of political

\footnotetext{
${ }^{1}$ This study was written with the support of a CEU IAS Senior Core Scholarship
} 
Valuch, Tibor. "Following the Life Stories of Participants in the 1956 Hungarian Revolution." Hungarian Cultural Studies. e-Journal of the American Hungarian Educators Association, Volume 9 (2016) DOI:10.5195/ahea.2016.253

resistance that continued until January 1957, roughly one-fifth of the seven million adults living in Hungary at this time played some type of a role in the 1956 Hungarian Revolution (Litván 1996, Szakolczai 2006). In communities throughout the country, revolutionary committees ousted Soviet-style town councils, placing local governments in the hands of an estimated 60,000 to 80,000 individuals. Factory plants, government offices, institutions, and manufacturies came under the direction of workers' councils, organized and led by a minimum of 80,000 to 100,000 participants. On a national level, the total number of those possessing membership in some type of political organization has been estimated at 140,000 to 180,000 people. In a secret survey prepared by the Ministry of Interior from 1958 to 1959, an average of five to six thousand individuals per Hungary's nineteen counties had files kept on their activities. When combined with those living in Budapest, this number expanded to include a total of 110,000 to 130,000 people. Spontaneously chosen for their positions, the revolution's political elite - such as the chairmen and assistant chairmen of revolutionary committees or workers' councils or committee secretaries - consisted of between 14,000 and 15,000 members on the national level. These figures indicate the extent of political activity conducted by Hungarian society during the period of the 1956 Revolution.

Between 1957 and 1961, the wave of reprisals and retribution that followed in the revolution's wake led to the execution of 229 individuals, while roughly 20,000 people spent shorter or longer periods in prison. About the same number of people could be found in internment camps in the years between 1957 and 1959 (Rainer 1987: 49-50). While exact figures are not available, it can be estimated that tens of thousands of people were removed from their jobs. During this time, communist leaders focused on either intimidating those who had been particularly active in the revolution, or rendering them incapable of action. When all else failed, individuals were forced to leave the country. In other words, the regime's goal was to neutralize all "key" individuals who may have been capable of establishing or operating any kind of political resistance movement.

In this study I will examine what aspects may have characterized the life paths of participants in the 1956 Revolution, both before and after these events unfolded. What experiences influenced their socialization and subsequent attitudes toward society? In the years of the Kádár regime, what effect did their roles in the revolution have on possible career options or the formation of their political attitudes? What changes did their network of friends and family undergo as a result? In short, how did the 1956 Revolution alter their fates and lives as individuals? With these findings as a foundation, broader conclusions can then be made concerning the 1956 Revolution's effect on Hungarian society during the latter part of the twentieth century.

In the 1990s, I prepared life interviews with fifty individuals who had participated in the revolution. Out of these subjects, the average age for those who had first been present during the events unfolding in Hajdú-Bihar County as well as Debrecen and then imprisoned for various lengths of time following the revolution's defeat barely exceeded that of twenty-five years. The youngest interview subject had just turned twenty when the revolution broke out, while the eldest had been forty-two years old at the time. All of them were men, a circumstance explained by the fact that political activity was still considered by Hungarian society at this time to be a matter best left to men. This claim is supported by the data that in the years following the revolution, out of the 658 individuals sentenced in Hajdú-Bihar County for their revolutionary activities, only twenty were women. In the course of preparing these interviews, it unfortunately proved impossible for me to reach any of these female participants. One-third of those selected for 
Valuch, Tibor. "Following the Life Stories of Participants in the 1956 Hungarian Revolution." Hungarian Cultural Studies. e-Journal of the American Hungarian Educators Association, Volume 9 (2016) DOI:10.5195/ahea.2016.253

interviewing had completed eight years of elementary education, while more than half had attained a secondary school education as well. Slightly fewer than one-fifth of the interviewees possessed university degrees (Valuch 1996).

Regarding their professions, in 1956 the majority had been occupied as skilled or unskilled laborers, farmers, or university students. At the same time, occupations such as that of military officer, teacher, engineer, railroad man, doctor, university professor, tradesman, or local artisan were also present. A significant majority had grown up in farming or working class families and displayed - in most cases - a strong tendency toward upwardly mobile professions as a result. Altogether one-sixth of the fifty individuals possessed a family background that could be described or qualified as some form of "class enemy" according to the communist phraseology used in this period. In these particular cases, one had grown up the child of a preacher, while the other came from a bourgeois family and was the son of a government bureaucrat.

For these interview subjects, the financial circumstances defining their family backgrounds display a great deal of variety. The two extremes could best be described as "respectable poverty" versus a financially secure, middle-class existence. No one mentioned anything indicating extreme poverty, or any other circumstances stemming from uncertain living conditions. At the time of the revolution's outbreak, the majority were either single or had only recently been married. This was naturally due to their ages at the time and also explains the relatively high level of freedom of movement they possessed. The majority also felt it important to indicate their family's religious background. Originally from the town of Hajdúböszörmény, Imre Lázár was a university student in 1956 and later recalled his background in the following words:

My parents belonged to the Eastern Catholic Church, a rarity in this mainly Calvinist region... for Catholics, religious practice meant church and mass was attended with far more intensity and frequency. Neither sides of my family were bigots, but they were churchgoers and my grandfathers on both sides had been members of the church council, as was my father for a time. This was the spirit in which their families were raised (interview with Imre Lázár).

\section{[A szüleim görögkatolikusok voltak. Ezen a református vidéken ez ritkaságnak számított. (...) a katolikusok vallásgyakorlása intenzívebb templomlátogatást, misére járást jelentett. A családomban nem voltak bigott emberek egyik részröl sem, de templombajárók és a családom mindkét ágában az egyháztanácsnak, a presbiteriumnak tagjai voltak nagyapám is, apám is egy ideig. Ebben a szellemben nevelték családjukat.]}

Given the distribution of religious denominations in Hungary, Calvinism's dominant role in this area of Eastern Hungary is to be expected. In contradiction to their open discussion of religious background, few subjects mentioned what communist affiliation the head of their family may have had. The reason for this may be that it was not nearly as common for members of their parents' generation to join the Communist Party, and few may have done so. At the same time, it is possible that the interview subjects simply did not find this information important enough to relay. 
Valuch, Tibor. "Following the Life Stories of Participants in the 1956 Hungarian Revolution." Hungarian Cultural Studies. e-Journal of the American Hungarian Educators Association, Volume 9 (2016) DOI:10.5195/ahea.2016.253

Their life stories and career paths during the period preceding the revolution show a great deal of variety. In reference to their family backgrounds, a significant number of interview subjects mentioned parents (primarily fathers) who had an interest in politics and public affairs. In other words, they grew up in households that were not only familiar with their daily environment, but also with local society and its leading members. Quite frequently, the subjects listed the important members of their own communities. Almost everyone emphasized how hard work and study had represented the only means of exchanging their given social status for a better one.

For many - mainly among older subjects-World War II and time spent in a prisoner-ofwar camp had been a definitive experience. Among those interviewed, many had been interred for various lengths of time in Soviet prison camps. Needless to say, everything they had endured either as soldiers fighting on the eastern front, civilians experiencing the advance of the Red Army, or as prisoners-of-war in the Soviet Union did not increase the Soviet regime's popularity.

Among those belonging to the younger generation, many had temporarily begun to make their way up in post-1945 Hungary as military officers, chief bureaucrats, or university students. These career advances were either completely or temporarily cut off in the beginning of the 1950s due to the totalitarian nature of the Rákosi regime, or later on due to participation in 1956. One subject was discharged from the military for "political unreliability," while another was dismissed from university after his bourgeois origins were discovered. According to the recollection of Károly Horváth, a young man in his twenties whose father had been a bureaucrat:

At that time an application could be submitted to multiple universities. I applied to the Budapest Technical University and sat for the entrance exam in the summer of 1954. Afterward I received the results, the wording of which I soon became very used to: 'sufficient marks on entrance exam, not admitted due to insufficient space.' This lasted for a whole three years. There wasn't a university in all of Hungary that had enough space for me...one time they sent all the application papers back - probably by mistake - together with my resume. I couldn't deny my father's profession, or the fact that we owned land. They knew it anyway. Nothing else in the entire application mattered, not even my perfect academic record. Just the fact that my father had been a chief notary (interview with Károly Horváth).

[Abban az idöben még olyan volt a felvételi rendszer, hogy több egyetemre lehetett beadni a felvételit. Én a Budapesti Müszaki Egyetemre jelentkeztem, ott felvételiztem 1954 nyarán. A felvételi után jött az eredmény-amit késöbb már nagyon megszoktam és ismerös volt - 'a felvételi vizsgán megfelelt, hely hiányában nem vesszük fel'. Ez tartott három éven keresztül, Magyarországon nem volt olyan egyetem, ahol számomra hely lett volna. (...) Egyszer a papírokkal együtt—biztosan véletlenül—visszaküldték az önéletrajzomat is. Nem tagadhattam el apám foglalkozását, azt hogy földje volt, mert ezt úgyis tudták. Az egészböl semmi más nem számított — a jeles tanulmányi eredmény sem—csak az, hogy apám föjegyzö volt.]

Having participated in the 1956 Revolution also provided sufficient cause for a variety of 
Valuch, Tibor. "Following the Life Stories of Participants in the 1956 Hungarian Revolution." Hungarian Cultural Studies. e-Journal of the American Hungarian Educators Association, Volume 9 (2016) DOI:10.5195/ahea.2016.253

political and social disadvantages.

One segment of the fifty subjects had become involved in personal or political conflicts before 1956. Since there were no instances of open, mass political resistance against the communist system in Hungary, it was unusual to come across someone who had been imprisoned for this type of activity (such as the distribution of illegal handbills) before 1956. In total, three had appeared in courts for political crimes (illegal border crossing, political incitement) between 1945 and 1953. At the same time, as the communist system strengthened its grasp, the heightened "battle of classes" and the logic of a totalitarian dictatorship demanded that the more elite, land-owning farmers among the peasant class be labelled as "kulaks" in imitation of the Soviet system. Similarly, various members of the bourgeoisie were labelled "class enemies" and faced being sent to internment camps, forcible deportation to a designated location, or continuous harassment by different economic and legal means (the levying of financial penalties, removal from the workplace, etc.). Many became scapegoats and enemies of the developing proletarian dictatorship by virtue of their family origins, without ever having committed any type of concrete, anti-communist activity (Valuch 2001).

For those who were older at the time, their ability to make a living and support their families presented a serious problem. As a farmer in his thirties at that time, József Csóra recalls the following memories:

Three times in a row they elected me head of the Hangya Association ${ }^{2}$ - the last time was in 1949, but they kicked me out after a while, kicked me out just like that. After this there was no way I could find a job, no way at all. Nobody'd even talk to me. That's how I lived my life. Making mudbricks, getting some of the harvest for working next to the threshing machine, any kind of work I could get, I did it. I learned how to repair rubber and fixed gumboots for people...it was all I could do to support my family. Later, I bought two horses and a wagon from the money left me by my parents so I could haul freight. Until that caught their eyes and they took that away from me, too...I had to work like a dog because by that time there were eight of us (interview with József Csóra).

[Háromszor egymás után választottak meg a Hangya Szövetkezetben vezetőnek, utoljára 1949-ben, de kisepertek egy idö után, szabályszerüen kisepertek. Énnekem utána soha nem lehetett, sehol elhelyezkedni. Még csak szóba sem álltak velem. Így éltem az életet. Vályogvetés, részes aratás cséplögép meletti munka, ami jutott nekem. Megtanultam a gumijavitást, gumicsizmákat javítottam. (...) A családot éppen fenn tudtam tartani. Később, abból, ami a szüleimtöl rám maradt, vettem két lovat és egy stráfkocsit, hogy fuvarozzak. Míg ezt is meg nem elégelték s elvették tölem. (...) Rengeteget kellett dolgozni, mert akkor már

\footnotetext{
${ }^{2}$ Established in1898, the Hangya Association was a national, economic association that operated to aid farmers by coordinating local organizations concerned with farm production, marketing, and consumption. After communist leaders took over the government in 1949, this association was nationalized.
} 
Valuch, Tibor. "Following the Life Stories of Participants in the 1956 Hungarian Revolution." Hungarian Cultural Studies. e-Journal of the American Hungarian Educators Association, Volume 9 (2016) DOI:10.5195/ahea.2016.253

nyolcadmagammal voltam.]

During this period, the conduct displayed by the majority of interviewed subjects was characterized by attempts to avoid conflict and remain unnoticed. In the event that they still found themselves running afoul of the system - not difficult to do given the constantly changing legal requirements and laws - their sense of caution only increased.

Based on these interviews, it appears that making the decision to take part in the 1956 Revolution was not influenced by any kind of concrete motivation stemming from family ties to a particular party or political thought pattern. It is, however, undoubtedly true that familial or personal behavior patterns, individual recognition, as well as a sense of prestige attained at the micro-community level played an indirect, yet still significant role in this decision. The other important factor influenced by the family environment is their slightly above-average familiarity with both political and general issues, openness toward taking on public roles and generally quick ability to make decisions. The personality characteristics shared by the majority of my interview subjects are best described as decisiveness, consistency, and a heightened need for personal autonomy.

Following World War II, only members of the older generation took on public roles during the brief parliamentary period lasting until 1948. This carried much more weight in 1956 as well, when at least part of the 1956 political elite emerged out of those who had already possessed leadership positions on local or national levels between 1945 and 1948. One-third of those interviewed had been members of the Communist Party (The Hungarian Workers' Party) and joined due to reasons such as personal conviction, the attempt to comply with social or political expectations, or even as a means of securing a career.

József Hevesy, age twenty-five at the time of the revolution, recounted how "in secondary school at the time, when Rákosi came to power, these new ideals spread like wildfire among young people, which I was pretty susceptible to, so I joined the Communist Party's youth organization. I filled different types of functions there, and when I was in my third year, I joined the Communist Party, too. As an enthusiastic young man, I was enthusiastic about these new ideals as well" [Annak idején a gimnáziumban, amikor jött a Rákosi-idöszak, a fiatalság körében elindult az új eszméknek a térhódítása, amire én eléggé fogékony voltam, így beléptem a kommunista párt ifjusági szervezetébe, ott különbözö fnkcióim voltak s amikor harmadikos gimnazista voltam, beléptem a kommunista pártba is. Mint lelkes fiatal, ezekért az új eszmékért én is lelkesedtem] (interview with József Hevessy).

In the case of Party members, during the year-and-a-half to two-year period preceding the revolution, the experience of gradually distancing themselves from - or, to be more precise, critically questioning their realization in daily life or politics - the ideals propagated by the system also proved to be a defining influence. Hevessy continued his account in the following words:

The first slap in the face came when I was in charge of overseeing the threshing and saw how it was all being carried out in practice-how the peasants were being stripped of their food supplies, how they were being made to supply even more...so I slowly grew more and more disillusioned. That's why I no longer held any type of function by the time I was at university, but still had my Party membership. This was in 1953. By the time 1956 came around, I was able to judge things far more clearly (interview with József Hevessy). 
Valuch, Tibor. "Following the Life Stories of Participants in the 1956 Hungarian Revolution." Hungarian Cultural Studies. e-Journal of the American Hungarian Educators Association, Volume 9 (2016) DOI:10.5195/ahea.2016.253

[Az elsö pofonokat akkor kaptam, amikor cséplési ellenör voltam és akkor kezdtem látni ennek a gyakorlatát, azt, hogyan söprik ki a parasztoknak a padlását, a begyüjtési akciókat. (...)Szóval lassan elindult egy kiábrándulási folyamat. Így, amikor az egyetemre kerültem már semmiféle funkcióm nem volt, a párttagságom viszont megmaradt. Ez 1953-ban volt. Amikor 1956 elkövetkezett, akkor már a helyzetet világosabban látó ember voltam.]

Most interview subjects named the inevitability of some kind of political change and their increased dissatisfaction with the politics of the time as the strongest motivation behind their decision to take personal action. Zoltán Mervó, a twenty-year-old engineer at the time, described the mood in the following words: "At this time there was a sort of feeling of expectation in the air. In the period after the 20th Congress, broader political issues were already popping up everywhere, from talks among friends to Party meetings"[Ebben az idöszakban már volt valamiféle várakozás a levegöben. A XX. kongresszus utáni idöszakban már baráti körben vagy pártgyülésen is elökerült a nagypolitika] (interview with Zoltán Mervó). A growth in increasingly strong national sentiment was the natural result of events pertaining to the revolution.

It comes as no surprise that these participants' political activity gradually increased in the days preceding October. While they also found it natural to take part in the initial movements leading up to the revolution, most were surprised to be appointed to the political posts or roles they had earned as an outcome of these events. In spite of this, almost all of those interviewed were able to meet the expectations meted out to them; this claim is supported not only by the interviews, but by other documents as well. They took control of the political bodies under their direction with relative speed and not much difficulty; they proved sufficient for the handling of community affairs abandoned in panicked haste by the fleeing members of the Rákosi administration. From this point on, everything that occurred became their own personal matter, which is why the revolution's eventual defeat was also a matter of their own personal defeat. The twenty-year-old worker Károly Horváth felt that:

On November $4^{\text {th }}$ it seemed that a great future had been lost, the future that would have made life worth living. It looked like all the hope we had felt for twelve days, all our feelings that things would be a bit better now, had gone up in smoke. We thought not everything had been totally lost-now was the time to turn to some form of quiet resistance and peaceful protest...we'd have to use other methods - like handbills - to let people know that everything that'd happened as of November $4^{\text {th }}$ was an extreme injustice and the dirtiest of deeds (interview with Károly Horváth).

[November 4-én úgy tünt, hogy elveszett az a nagyszerü jövö, amiért érdemes lenne tovább élni. Megsemmisülni látszott az a remény, amit a 12 nap mutatott, hogy most már kicsit jobb lesz mindenkinek. Úgy gondoltuk, hogy még nincs minden veszve, és most ilyen csendes tiltakozásra, csendes ellenállásra kell átállni. (...) Különbözö eszközökkel - röpcédulázásokkal is - valami jelt kell adni, hogy ami november 4-én és azt követöen történt, égbekiáltó igazságtalanság és gazemberség volt.]

For a small number of interview subjects, it was precisely this experience of lost freedom 
Valuch, Tibor. "Following the Life Stories of Participants in the 1956 Hungarian Revolution." Hungarian Cultural Studies. e-Journal of the American Hungarian Educators Association, Volume 9 (2016) DOI:10.5195/ahea.2016.253

that motivated them to take part in political struggles after November $4^{\text {th }}$, thereby attempting to establish organizations and forms of political resistance. According to the experienced, thirtyseven-year-old skilled laborer, László Zeke, this is also what inspired him to take part in politics:

The fact that those dirty Soviets had destroyed such a miraculously beautiful, such a great revolution - that somehow spurred me on to make sure there'd be an honorable end to it all. This beautiful revolution just could not remain disgraced the way it had been on November $4^{\text {th }}$. To make things worse, as days went by, it became more and more obvious that everything was on its way back, everything was going right back to where it had been. There was just no way this could be allowed to happen (interview with László Zeke).

[Az a körülmény, hogy szétvertek egy ilyen szép és csodálatos, egy ilyen gyönyörü forradalmat ezek a piszkos szovjetek, valahogyan arra ösztönzött engem, hogy becsületes vége legyen a dolognak. Ezt a szép forradalmat nem lehet úgy meggyalázni, ahogy azt november 4-én tették. Ráadásul, ahogy teltek a napok, egyre inkább rá kellett döbbeni, hogy itt minden visszafelé forog és minden oda fog visszamenni, ahonnan elindult. Ezt nem lehetett annyiban hagyni.]

Particularly by the end of 1956 and the beginning of 1957 it appeared that events could no longer be reversed: this feeling of defeat was an intrinsic force in determining what personal survival strategies would be utilized. Other than the option of fleeing from the expected ordeals resulting from reprisals, this feeling made the thought of remaining in Hungary absolutely untenable and therefore drove many to opt for emigration instead.

It can also be surmised that this feeling of irreversibility was what rendered the idea of further political resistance senseless following the first month of 1957. The sheer hopelessness of continuing to struggle against dictatorship managed to wipe out even the thought of holding any public remembrance of the revolution. Other than this knowledge of defeat, it must not be forgotten that precisely those individuals who would have been capable of organizing political resistance were no longer present: if not in prison or abroad, the few who remained in Hungary were thoroughly dissuaded from attempting this type of action by the "daily terrors" of the Kádár era.

Immediately after the revolution, among the ones who had been active on those October days there were some who felt it better to leave the country, while others felt they were guilty of no crime; as chosen members of new, political organizations, they had simply been maintaining order. To their minds, it seemed they would not be subjected to any kind of retribution and therefore did not flee. As a result, their subsequent arrest caught them unaware and completely unprepared. Together with the physical abuse and frequently lengthy amount of time involved in the sentencing process, the years spent in prison caused severe mental, spiritual, and physical stress, yet rarely led to the distortion of their personalities. The aid provided by those sharing the same fate, being surrounded by a community of others all suffering the same indignities, the concept that they represented the cause of social justice as well as their belief in their own innocence helped most of them to withstand this extremely unbearable time. A young skilled laborer working in the chemical industry at the time, László Szücs had the following recollections regarding this period:

After the sentencing we went back and everyone tried to build his life as best as 
Valuch, Tibor. "Following the Life Stories of Participants in the 1956 Hungarian Revolution." Hungarian Cultural Studies. e-Journal of the American Hungarian Educators Association, Volume 9 (2016) DOI:10.5195/ahea.2016.253

possible. There, for a little while, everything just broke in two... when the judge announced the sentence, at first I just thought, all right, fine, I'll serve my time and then something'll come afterward... while I was in prison, I couldn't think of anything else, just that tomorrow I'd be out of there...really enormous tragedies were taking place all around us in jail — nervous breakdowns one after the other. I, with all my twenty-two years, just told myself that this was what I'd have to serve and I'd have to do my best to get through it (interview with László Szücs).

[A tárgyalás után visszamentünk és mindenki próbálta a maga életét újra felépiteni, úgy, ahogy tudta. Ott egy pillanatra egy kicsit megszakadt minden. (...) Mikor a biró kimondta az itéletet, az első pillanatban úgy fogtam fel-na jól van, akkor ezt leülöm, majd valami lesz utána. (...) A börtönben nem járt más az eszemben, mindig csak az, hogy holnap szabadulok. (...) Nagyon nagy tragédiák történtek a börtönben, jöttek az idegösszeomlások. Én, 22 éves fejjel megbeszéltem magammal, hogy ennyit kell kitölteni és megpróbáltam valahogy ehhez igazodni.]

It therefore follows that those who found themselves imprisoned commonly felt their punishment to be unlawful; the majority entered a plea of not guilty in court as well. While it comes as something of a paradox, most look back on their years in prison as a positive experience, in spite of the lack of freedom, being cut off from the world outside and their utter defencelessness in the face of their captors. Many felt that they had never been before, nor ever were thereafter surrounded by such good company as they were during the time of their captivity. Even more - especially among the younger subjects-looked back on their incarceration (or at least some of it) as a good school of sorts, a special kind of intellectual experience. This was primarily due to the relatively high level of education possessed by the prisoners, as well as the strong bonds forged by their common experiences and the feeling of camaraderie that therefore resulted. The 1956 Revolution's political prisoners quite possibly possessed an above-average ability to create their own community, a community that could not be broken by either their enforced, close quarters, or the personal conflicts stemming therein.

By its very nature, imprisonment naturally entailed a variety of severe, nearly unbearable personal conflicts. Anyone incapable of adapting to the strict order, the cramped living quarters and the mental burden of being locked up tended to perpetuate these conflicts. Among all the daily afflictions and inner turmoil brought about by life in prison, the most severely felt one was their worry for their families. This worry was compounded by the guilt of having committed acts that placed their families at risk. Leader of the workers' committee in Debrecen in 1956, László Zeke, described the situation thus:

For a while I was kept in a tiny prison cell, where the wall was so close to the edge of my cot there was barely any room to walk...there was really only one thing that bothered me. I didn't care that I was locked up inside because they thought I'd committed crimes. I couldn't handle the fact that while I was there, being watched over and fed, my wife was out there with two kids to take care of, without any food or support. She couldn't get a job anywhere. This injustice hurt so badly that there were a lot of times when I just about went crazy from it (interview with László Zeke). 
Valuch, Tibor. "Following the Life Stories of Participants in the 1956 Hungarian Revolution." Hungarian Cultural Studies. e-Journal of the American Hungarian Educators Association, Volume 9 (2016) DOI:10.5195/ahea.2016.253

[Egy darabig egyedül voltam egy pici cellában, ahol a priccs és a szabadon maradt fal között jóformán sétálni sem volt hely. (...) Engem egy dolog zavart igazán. Nem az, hogy én bent vagyok, mert szerintük bünöket követtem el, hanem az, hogy amig itt engem öriznek, etetnek, addig a feleségem ott maradt két gyerekkel, kenyér nélkül, támasz nélkül. Sehol nem kapott állást, Annyira fájt nekem ez az igazságtalanság, hogy sokszor majd beleörültem.]

Supporting their families had become increasingly difficult, a circumstance only rarely eased by the help and solidarity of friends and colleagues (including individual aid or ad hoc food and clothing collections). The brunt of this incredible burden was placed on the shoulders of wives forced to take on the role as head of the family. The spouses of anyone sentenced to prison for 1956 were frequently fired from their positions, while finding a new job was made either extremely difficult or rendered impossible. Also stripped of his rank as officer, many decades after these events had passed Imre Garab still spoke bitterly of this period: "My wife couldn't get a job in Debrecen, so she went to Sopron and moved back to her parents' so she wouldn't be living off my parents. For a long, long time she wasn't deemed fit even for sorting dried peas. She couldn't get any kind of temporary job either. All because her husband was a rotten counter-revolutionary" [A nejem Debrecenben nem tudott elhelyezkedni, mert Sopronból, hogy ne éljen az én szüleim nyakán, visszaköltözött az ö szüleihez és hosszú ideig még borsóválogatásra sem vették fel, alkalmi munkát sem kapott, mert a férje rohadt ellenforradalmár] (interview with Imre Garab). Nor were children exempt from these repercussions; the children of people imprisoned for 1956 were much less likely to receive schooling or be able to attain an advanced degree (Körösi-Molnár 2003). By the second half of the 1960s, this practice of extending punishment to include family members slackened in severity.

While this disadvantageous situation and the political discrimination it incurred took on various forms and methods, it still followed these individuals for the rest of their lives and -in some cases - caused differing degrees of mental health issues. The Kádár regime took conscious steps to keep anyone who may have posed a potential threat to the system as marginalized as possible, both politically and on the level of daily survival. Later, as consolidation gradually moved forward, this marginalization of existential means could slowly be decreased. Thus began the era of "licensed freedom" (Rainer 2011).

Other than the initial euphoria of having regained their freedom, release from prison brought with it the severely limited feeling that a certain kind of justice had been served. Primarily for the "long-timers" released during the amnesty proclaimed in 1963, this initial impression was quickly followed by disillusionment and bitter shock: by the time they had been

\footnotetext{
${ }^{3}$ In the period following the 1956 Revolution a unique type of prison slang evolved in the Hungarian language. The "long-timers" or "big-timers" were those serving five to ten-year (or even longer) prison sentences. The "shorttimers" or "little-timers" were those sentenced to less than five years. Those given the unofficial title of "His Grace" had been sentenced to death on either the first or (more unusual) second degree, but were eventually granted clemency and had their death sentences reduced to the "grace period" of a life sentence or fifteen years in prison.
} 
Valuch, Tibor. "Following the Life Stories of Participants in the 1956 Hungarian Revolution." Hungarian Cultural Studies. e-Journal of the American Hungarian Educators Association, Volume 9 (2016) DOI:10.5195/ahea.2016.253

freed, 1956 was a taboo topic as far as Hungarian society was concerned. By society at large, solidarity toward the revolution, or for those who had made serious sacrifices for its cause, was only felt occasionally - if at all. As was recalled by Zoltán Simon, a university student at the time of the revolution, "this was a time when the fact that I'd say hello to someone and be ignored was the least of my problems. Sometimes they didn't even want to recognize me, or even talk to me. Or they stood there and said, yes, well, what can you do- then I heard later the same person had shut the door behind him and called me a dirty counter-revolutionary" [Ez egy olyan idöszak volt, amikor az, hogy nem köszöntek vissza, az volt a legkevesebb. Idönként meg sem akarták ismerni az embert vagy szóba sem álltak vele vagy pedig a szemébe mondták, hogy hát igen - és késöbb hallotta vissza az ember, hogy amikor behúzta az ajtót, azt mondták, hogy ez a piszok ellenforradalmár] (interview with Zoltán Simon). With much difficulty, the support of close friends and family could only partially surmount this lack of social solidarity. For many, the fact that the Hungary they found upon their release was a completely changed country where the majority viewed them not as heroes, but as victims at best and fools at worst, led to psychological wounds that never healed.

Many — particularly among the "long-timers" who had served lengthy prison periodsfound it important to mention how out-of-place they felt upon release. They moved hesitantly and felt uncertain on the streets. After their predictable prison routine, adjusting to the constant stimulation provided by everyday life was not easy; conquering the sudden panic they felt in confronting the unknown, outside world required serious effort. Miklós Dubay, a physician elected a member of the revolutionary committee in Berettyóújfalu during 1956, provided a telling account of his experiences:

I was afraid. Having all those people around me was terrible. I thought they were watching me and knew I'd been in prison...I didn't want to go outside, I had to be forced to leave the house. The house felt safe, but I couldn't handle all the people rushing up and down the streets. It took a really long time for me to accept that I could go wherever I wanted. I could even buy a pack of cigarettes if I felt like it. It was strange to be wearing normal clothes and not my prison uniform. So I bought myself a pair of dark glasses and for a while that was the only way I could walk out onto the street. I thought that if I wore glasses, all those people racing around so happily wouldn't be able to tell what a musty jailbird I am (interview with Miklós Dubay).

[Féltem. Rettenetes volt az a sok ember. Mindig azt hittem, hogy engem néznek és biztosan látják rajtam, hogy börtönben voltam.. Nem akartam kimozdulni, úgy cipeltek ki az utcára. A lakásban biztonságos volt, de az utcán az emberek rohanása zavart. Hosszú ideig tartott tudomásul venni azt, hogy oda megyek, ahová akarok. Ha úgy tetszik veszek egy doboz cigarettát. Furcsa volt, hogy nem rabruha volt rajtam, hanem normális öltözék. Szóval vettem magamnak egy sötét szemüveget és egy ideig abban mentem az utcára. Azt hittem, hogy akkor nem látja rajtam az a sok boldog ember, aki itt szalad, hogy egy penészszagú börtöntöltelék vagyok.]

Twenty years old at the time of his incarceration, Károly Horváth related the following, 
Valuch, Tibor. "Following the Life Stories of Participants in the 1956 Hungarian Revolution." Hungarian Cultural Studies. e-Journal of the American Hungarian Educators Association, Volume 9 (2016) DOI:10.5195/ahea.2016.253

similar memories concerning the period after his release: "In those first few days everything was frightening and unfamiliar because I felt like I was in a completely different world. At first everything bothered me. The coffee tasted sour, the beer was awfully bitter. After the bland food we got in prison, everything tasted far too strong. I really couldn't handle all the people walking on the streets. I was too afraid" [Félelmetes és szokatlan volt az elsö pár nap, mert egy egészen más világba cseppentem át. Az első idöben minden zavart. A kávé savanyú volt, a sör nagyon keserü. Az egyhangú börtönkoszt után mindennek nagyon erös ize volt. Az utcán pedig a rengeteg ember most nagyon zavart. Féltem] (interview with Károly Horváth).

Quite understandably, once they were released most of those who had served time for 1956 turned their energies toward rejuvenating and reinforcing their family ties. While in prison, family had come to mean everything. For the most part, their family background made it far easier for them to find their way back into society; for a minority, however, the years in prison had cost them their marriage, their families. At the same time, there were also examples of couples who made the decision to divorce once the sentence had been declared, but remarried later on, following release.

For these former political prisoners, there were just as many degrees of variation in how they were able to return to work as there were for those who had "only" lost their jobs, or been subjected to disciplinary actions by a university or workplace for their role in the revolution. At first employment was generally out of the question; they were later allowed to get a job as an unskilled or skilled laborer of some type. Eventually, they were able to attain a workplace that more closely resembled their original field or level of training. By the latter half of the 1970s, obstacles were generally not placed before them working in their original capacities and positions. The university student Imre Lázár underwent a lengthy series of trials and tribulations before he was finally able to complete his studies:

I wasn't allowed to go back to university because the court explicitly decreed that I was to be shut out of all universities in Hungary for an unspecified amount of time. There was naturally no way for me to find the kind of work that would have corresponded to my level of education or - to put it more accurately - my level of training at the time. So I worked as a day laborer on farms in Hajdúböszörmény, took on odd jobs until the end of autumn, then I packed freight cars at the railroad from winter till late spring. Later on I became a shop assistant at a bookstore and worked there for years. After this I ended up at the city library in Hajdúböszörmény. It was already the middle of the sixties, but I still couldn't get accepted to any kind of university. In 1969 I finally finished my degree, but couldn't get a teaching position...I worked in the library and even got qualified as a librarian. I eventually accepted the fact that I wouldn't be allowed to teach" (interview with Imre Lázár).

[Az egyetemre nem mehettem vissza, mert a birósági végzés egyértelmüen azt jelentette, hogy Magyarország összes egyeteméröl meghatározatlan idöre kizártak. Olyan munkáról, ami az én akkori végzettségemnek, pontosabban az akkori szakképzettségemnek megfelelt volna, természetesen szó sem lehetett. Úgyhogy Hajdúböszörményben mezögazdasági napszámra jártam, alkalmi munkákat vállaltam az ösz végéig, ezután a téli időszakban a vasútnál vagont raktam késö tavaszig. Késöbb könyvesbolti eladó lettem, évekig itt dolgoztam, 
Valuch, Tibor. "Following the Life Stories of Participants in the 1956 Hungarian Revolution." Hungarian Cultural Studies. e-Journal of the American Hungarian Educators Association, Volume 9 (2016) DOI:10.5195/ahea.2016.253

aztán a hajdúböszörményi városi könyvtárba kerültem. Ez már a hatvanas évek közepe volt, de még mindig nem végezhettem el semmiféle egyetemet. Végül 1969ben befejezhettem az egyetemet, de tanári állást nem kaphattam. (...) A könyvtárban dolgoztam, könyvtárosi képesítést is szereztem. Végül elfogadtam azt az állapotot, hogy nem taníthatok.]

For those originally from the countryside, it was rather common for them to begin rebuilding their lives and careers in either the capital city, or in other parts of the country distant from their previous homes or workplaces. They usually only returned home after a few years had passed. This generally depended on the extent to which the individual had come into conflict with local officials at the time of the revolution. A lengthy amount of time passed before the former officer, Imre Garab, was able to find a job in Budapest following his release:

I couldn't get a job anywhere. They thought I was fine up until the minute I had to provide information about my professional experience. When they took a look at my employment record, then came the question: where were you from 1956 to 1959? Prison, I always answered. From that point on, the better places told me they'd contact me later, but never did. Other places just said they'd never employ someone from '56. I went from factory to factory, but no luck. Finally-with some help-I started working as an assistant locksmith" (interview with Imre Garab).

[Elhelyezkedni nem tudtam. Addig, amíg a szakképzettségröl kellett szolgáltatni adatokat, addig a pillanatig jó voltam. Mikor megnézték a munkakönyvemet, jött a kérdés: hol volt ön 1956-tól 1959-ig? Mindig megmondtam, hogy börtönben. Abban a pillanatban a jobb helyeken azt mondták, majd értesítjük, de sohasem értesítettek. Volt, ahol megmondták, hogy ötvenhatost nem alkalmaznak. Gyárrólgyárra mentem, sikertelenül. Végül-segítséggel - lakatos segédmunkásként kezdtem dolgozni.]

No matter where they found themselves, 1956's former participants were "naturally" perfectly aware of how untrustworthy they were in the eyes of their workplace's leadership. If this process of discriminatory adaption were placed along a timeline, then its first two phases (unemployment and unskilled labor) mainly occurred during the first half of the sixties, the final years of consolidation for the Kádár regime as well as the beginning of the period of consolidation that followed the 1963 amnesty. During the seventies and eighties, the discrimination gradually decreased, but only stopped completely at the end of the eighties, when communism fell. The disadvantages that sprang from officially being barred from society could only be lessened by the solidarity of personal relationships, acquaintances, and the support of friends, new and old alike. In order to get a better job (or at least one that better suited the individual's original function) and therefore shorten the road leading out of marginalization, these informal connections generally proved adequate. This case, however, was not widespread and mainly occurred among those who lived in larger towns, possessed better educations and had 
Valuch, Tibor. "Following the Life Stories of Participants in the 1956 Hungarian Revolution." Hungarian Cultural Studies. e-Journal of the American Hungarian Educators Association, Volume 9 (2016) DOI:10.5195/ahea.2016.253

a broader network of connections.

The understanding of colleagues or the successful completion of a task provided a balm toward easing the pain of readjusting to society or these individuals' feelings of helplessness. After years of imprisonment, the former tobacco factory worker, László Zeke, met with both suspicion and solidarity:

I had to find work. For a while I worked at the Budapest Heating Plant. My wife and I had meanwhile gotten remarried and by the end of 1964 I was able to go back to Debrecen, to the Board of Water Management. I worked there all the way through my sixties, which was really good for me because among the people there I could shake the feeling that my past made me a lesser person, which really bothered me. Not that I was ashamed of the things I had done in 1956-but I obviously knew they were keeping an eye on me at my job and checked up on me now and then, which was, well, expected (interview with László Zeke).

[Állást kellett keresnem. Egy ideig a Budapesti Fütőerömünél dolgoztam. Közben újra elvettem a feleségemet, majd 1964 végén sikerült visszakerülnöm Debrecenbe, a Vizügyi Igazgatósághoz és itt dolgoztam egészen hatvanéves koromig, ami nagyon jól esett, mert itt az emberek között elfeledtem a kisebbrendüségi érzésem a múltam miatt, ami nagyon zavart. Természetesen nem azért, mintha szégyeltem volna mindazt, amit 1956-ban tettem. Nyilván azt is tudtam, hogy szemmel tartanak és idönként ellenöriznek a munkahelyemen, de hát ez ezzel járt.]

Mainly among those living in small communities, possessing lower educations and bluecollar professions, the conscious attempt to avoid regular contact with former prison mates was characteristic. For those with higher levels of education and generally employed in white-collar professions, their sense of caution slowly faded in the years following their release, yet their contacts remained mainly personal or professional in nature. This factor changed around the end of the seventies, beginning of the eighties, at which time their contacts became more political. This process of "activation" naturally came to the notice of the political police, whose attention was not restricted to this particular circle, but included all former political inmates of 1956 . The majority were aware of this, as was Imre Garab, who worked as a skilled laborer at the time: "In 1972 I heard from personnel that there's a file about me at the Political Police saying — among other things - that I am a well-known counter-revolutionary in Hajdú-Bihar County. This followed me wherever I went for the rest of my life" [1972-ben megtudtam egy személyzetistöl, hogy a Politikai Rendörségnél van nyilvántartási kartonom, amin többek között az is szerepel, hogy Hajdú-Bihar megyében közismert ellenforradalmár vagyok. Ez aztán végig kísért az. életemben] (interview with Imre Garab). As a result, these individuals almost always — at least until the end of the 1980s - felt far too exposed and vulnerable. Plagued by a sense of insecurity far greater than average, most stayed on the side of caution and withdrew to their private lives. This caution was mainly evident in their attempts to fulfil (at least formally) the system's expectations while also taking great pains to steer clear of any type of public role or attention, be it private or professional in nature. Even the inevitable demands of local or work events were avoided in their fear of being compromised.

At the end of the eighties, taking active part in movements working to transition from a 
Valuch, Tibor. "Following the Life Stories of Participants in the 1956 Hungarian Revolution." Hungarian Cultural Studies. e-Journal of the American Hungarian Educators Association, Volume 9 (2016) DOI:10.5195/ahea.2016.253

communist to a democratic system was mainly done by those in more intellectual positions. Many entered the parliamentary and local elections held in 1990 and took on roles as parliamentary or town representatives, leaders of national institutions, or political parties, mayors, or deputy mayors.

Among 1956's former participants, there were some who chose the easier route of serving the political system. The exact number of individuals from 1956 who worked as informants for the political police is still unknown due to the ambiguous way in which the issue of secret agents has been handled in post-communist Hungary. Except for one or two concrete cases, this lack of information makes it impossible to reconstruct what motivated the decision to record the movements of others.

The extraordinary way in which a portion of former 1956 participants were able to overcome the disadvantages stemming from their marginalization also deserves note. Among my interview subjects, the proportion of those who turned these disadvantages into advantages - at least in the figurative sense - was slightly larger. While these individuals were mostly in intellectual fields, once the eighties ushered in a more liberal atmosphere for starting up private businesses, there were also a few successful businessmen and tradesmen among them. Members of this group possessed an above-average level of mobility and opportunities. After being discharged from the military due to his time spent incarcerated, the military officer, Ferenc Nagy, tried to make his way by returning to his original trade as a cobbler:

I always worked at home, without an official license. After a while my wife and I decided to get the license and go into trade. Once I'd completed the necessary apprenticeship period, I took the exam to become a master of my craft and began working at home because I didn't have a shop of my own at first. Later on I opened that, too. I worked day and night. This was how this house where we're sitting now got built... Of course the tax agents made sure to hassle me, but after a while I got the hang of how to keep them quiet - after all, they lived off the market, too. Once I got through the first, hard steps, I did well as a private tradesman (interview with Ferenc Nagy).

[Mindig dolgoztam engedély nélkül itthon. Egy idö után a feleségemmel úgy döntöttünk, hogy kiváltom az engedélyt és kisiparos leszek. A szükséges gyakorlat után letettem a mestervizsgát és elkezdtem dolgozni itthon a lakásomon, mert akkor még nem volt üzlethelyiségem, késöbb aztán lett az is. Éjjel-nappal dolgoztam. Ez a ház is ebböl lett. (...) Persze az adóellenörök gyakran piszkáltak, de az ember egy idö után abba is beletanult, miként lehet öket elhallgattatni, mert ök is a piacról éltek. A kezdeti nehézségek után szépen boldogultam magánvállalkozóként.]

One part of this group was typically made up of individuals who were first-generation university graduates, had started their lives in an intellectual field, but originally came from working-class families. The other part originated from a white-collar background. Both cases were characterized by an initial attraction to the communist movement, followed by a gradual distancing from communist ideals. During the revolution, they entered leadership positions in cities or larger communities, then spent a lengthy time in prison. Once they were released, 
Valuch, Tibor. "Following the Life Stories of Participants in the 1956 Hungarian Revolution." Hungarian Cultural Studies. e-Journal of the American Hungarian Educators Association, Volume 9 (2016) DOI:10.5195/ahea.2016.253

rebuilding their lives took a few detours, but their circumstances gradually improved. The most characteristic example of this other group is the former military officer who came from farming roots, acted in a military capacity in 1956, then returned to his original profession after prison. From the 1970s, he worked in trade, then-taking advantage of the increase in available opportunities in the 1980s - opened his own business and became a successful tradesman.

Another issue common to a minority of these individuals was that the consequences of participating in politics led to severe conflicts in their private lives and increased the chance of various forms and degrees of deviant behaviourisms to develop. These individuals generally had a much lower level of education, their jobs in physical labor provided them with limited social mobility and their family situation was uncertain. This is best illustrated by the case of the mason from Debrecen who grew up as an orphan in foster homes and an orphanage. Toward the end of the forties, he quit masonry for the military, but returned to his original profession upon release from prison. He first worked as a laborer, then a skilled laborer before eventually regaining his status as mason. Since the years in prison had destroyed his marriage, he and his wife divorced soon after his release. At this point alcohol became his only refuge and he subsequently lost the opportunity to go into business for himself, a chance he had come close to achieving.

For the third and perhaps largest group, their living circumstances and situation - as meant in the sociological sense-were only slightly affected by the fact that they had participated in the 1956 Revolution. These individuals hardly changed professions after the revolution; in spite of the shorter or longer forced detour their lives took, they afterward returned to the jobs they had had before 1956 and generally cannot be described as attaining any kind of mobility.

This third group can be most aptly described through the life story of a cobbler from Bihar. First of all, if such a thing actually exists, this individual perfectly embodies the concept of "the little man," the one who never consciously chooses to have a role in the kind of social and political upheaval an event like 1956 was. The main ambition for this kind of person is survival, or at best the ability to make and maintain his own living. Born into a Calvinist farming family at the end of the 1910s in a small community located in Bihar, he started out as an apprentice cobbler for a short while before becoming drawn to the military in 1941. Hoping to gain a stable livelihood, he joined the local csendör ${ }^{4}$ unit and served throughout the rest of the war. In the beginning of 1945, he was taken to a prisoner-of-war camp in the West. A few months after his return to Hungary, he was removed to the Soviet Union, where he spent nearly six years in the gulag. When he was finally allowed to return home in December 1950, he was taken directly off the train and wound up in an internment camp for being an enemy of the system. He was freed from this camp in August 1953. While living in the shadow of constant police supervision, he started a family and was beginning to make a life for himself by 1955, at which time history once again stepped in. Intent on farming and more inclined to avoid events rather than take part in them, the cobbler was elected commanding officer of the national guard unit being organized in his village, a decision made on account of his family ties and reputation as someone familiar with weapons. He accepted the post and made all necessary steps to

\footnotetext{
${ }^{4}$ This term refers to a type of unit used to maintain public order and was somewhat similar to the French gendarmerie; in Hungary, however, it possessed far more jurisdiction and fewer limitations in comparison to units found in Western Europe.
} 
Valuch, Tibor. "Following the Life Stories of Participants in the 1956 Hungarian Revolution." Hungarian Cultural Studies. e-Journal of the American Hungarian Educators Association, Volume 9 (2016) DOI:10.5195/ahea.2016.253

establish the national guard and thereby maintain order. Throughout the entire revolution, nothing unusual occurred in this village. When the revolution ended, the cobbler was therefore fairly justified in thinking he could return to his everyday life. This, however, was not what happened: in 1957, while under interrogation, he was brutally beaten by the Kádár regime's police and-from this point on-came under official investigation. From time to time he was placed under police observation until finally, in the spring of 1959 , following multiple court appearances he was sentenced to one year in prison. In the winter of 1960, his sentence was reduced by one-fourth of its original length due to good behaviour, a practice at the time called negyedkedvezmény that was occasionally extended to political prisoners as well.

By this time the collectivization of agricultural lands was slowly drawing to a close, yet still resulted in the loss of his few acres of land. At first he earned a living doing odd jobs, unskilled labor, or hauling rubble at construction sites. Two years after his release from prison, he was employed by the local cobbler at the state collective and remained here until retirement. Like so many others, he "naturally" supplemented his income by working under the table and growing small crops on officially allotted household plots. He raised his children, helped them to gain an independent living, lived and still lives a modest lifestyle, far from public view. What is more, he discusses his past with an openness that is not only engaging, but also refutes no aspect of it, not even his "shadier" role as a csendör officer. Following his prison release in 1960, he kept himself far away from politics and only accepted a role as church deacon, a family tradition. While he did not become a member of any political party after communism fell, he did join the National Association of Political Prisoners. After 1990, he leaned toward supporting the Christian Democrats in elections.

The fates dealt out to those who participated in the 1956 Revolution encouraged the majority of Hungarian society to practice caution, withdraw from the public eye, and make personal compromises. Rebelling against the regime was seen as the least attractive of alternatives. At the same time, the examples of these individuals also had a large impact on the development of a social psychology sharply attuned to the practical matters of day-to-day survival. For decades, this mechanism was upheld by the way in which they mentally disassociated themselves from the revolution and withdrew to the private sphere. For well over three decades, the painful humiliation, incredible ordeals, and forced changes in career paths experienced by those who fought in the 1956 Revolution was a mindful warning and ready weapon in the hands of a one-party system determined to retain its power and neutralize any societal attempt to practice political sovereignty.

\section{Works Cited}

Körösi, Zsuzsanna and Adrienne Molnár. 2003. Carrying a Secret in my Heart: Children of the Victims of Reprisals after the Hungarian Revolution in 1956. Budapest and New York: CEU Press.

Litvan, Gyorgy ed. 1996. The Hungarian Revolution of 1956: Reform, Revolt and Repression, 1953-1963. London and New York: Longman.

Rainer, János M. 1987. "Adatok az 1956-os forradalmat követő megtorláshoz" ['Data on the Retaliation following the 1956 Revolution']. Beszélö. 19: 43-63.

—. 2011. Bevezetés a kádárizmusba ['Introduction to Kadarism']. Budapest: 1956 os Intézet-L'Harmattan Kiadó.

Szakolczai, Attila. 2006. "The People of the Countryside.” In 1956: The Hungarian 
Valuch, Tibor. "Following the Life Stories of Participants in the 1956 Hungarian Revolution." Hungarian Cultural

Studies. e-Journal of the American Hungarian Educators Association, Volume 9 (2016) DOI:10.5195/ahea.2016.253

Revolution and War of Independence. Eds. Lee Congdon, Béla Király, and Károly Nagy. New Jersey: Boulder - Social Science Monographs - Atlantic Research and Publications: 398-412.

Valuch, Tibor. 1996. Ötvenhatosok ['Fifty-sixers']. Debrecen: Cívis Kiadó. . 2001. Magyarország társadalomtörténete a XX. század második felében.

['The Social History of Hungary in the Second Half of Twentieth Century']. Budapest: Osiris.

\section{Annotated List of Interviews}

József Csóra (1919-2004) Farmer, merchant. Member of the leadership for the Berettyóújfalu Revolutionary Committee in 1956, sentenced to four years in prison in 1958. Following his release, he continued to make his living by farming. Interview with József Csóra. Berettyóújfalu, 1992. Oral History Archive, Budapest, no. 447.

Miklós Dubay (1928-2012) Physician. President of the Berettyóúffalu District Revolutionary Committee in 1956, sentenced to seven years in prison. Once released, he was eventually able to return to medicine and was physician to István Bibó at Korányi Hospital in Budapest. Interview with Miklós Dubay. Budapest, 1992. Oral History Archive, Budapest, no. 421.

Imre Garab (1930-2010) Military officer. Leader of the Special Police Section of the Debrecen Socialist Revolutionary Committee in 1956. In 1957 he was first sentenced to life, which was decreased to four years' imprisonment. After his release in 1959, he initially worked as an unskilled laborer, then as a skilled laborer. Interview with Imre Garab. Budapest, 1991. Oral History Archive, Budapest, no. 382. József Hevessy (1931-2005) Physicist, electric engineer. As assistant professor at the Lajos Kossuth University of Sciences in Debrecen, he was one of the initiators and organizers of political resistance and was sentenced to three years' prison in 1957. From 1990 to 1998 he served as mayor of Debrecen. Interview with József Hevessy. Debrecen, 1992. Oral History Archive, Budapest, no. 46.

Károly Horváth (b. 1936) Chemical technician. Participant in political resistance in Debrecen after November 4th, 1956; sentenced to seven years' prison in 1957. Later worked as an unskilled laborer, then chemist. Interview with Károly Horváth. Debrecen, 1992. Oral History Archive, Budapest, no. 437.

Imre Lázár (1935-2016) Librarian, teacher. Press official for the Debrecen 1956 Socialist Revolutionary Committee. In 1958 he was sentenced to one year in jail. From 1990 to 2002 he was mayor of Hajdúböszörmény. Interview with Imre Lázár, Hajdúböszörmény, 1992. Oral History Archive, Budapest, no. 427.

Zoltán Mervó (b. 1935) Mechanical engineer. Member of the Debrecen Socialist Revolutionary Committee in 1956, head of the workers' committee at the Factory of Medical Equipment. In 1957 he was sentenced to six years' incarceration, but this decision was appealed and in April 1958 he was sentenced to one year, eight months in prison. He first worked as a technician, then engineer. Interview with Zoltán Mervó. Debrecen, 1992, Oral History Archive, Budapest, no. 393. 
Valuch, Tibor. "Following the Life Stories of Participants in the 1956 Hungarian Revolution." Hungarian Cultural Studies. e-Journal of the American Hungarian Educators Association, Volume 9 (2016) DOI:10.5195/ahea.2016.253

Ferenc Nagy (b. 1929) Military officer, cobbler. Commanding officer of the national guard unit in Debrecen during 1956 and sentenced to one year in prison in 1957. He later worked as a cobbler, then a tradesman. Interview with Ferenc Nagy. Budapest, 1993. Oral History Archive, Budapest, no. 496.

Simon Zoltán (b. 1935) Teacher, editor. One of the organizers of a protest staged by university students on October 23, 1956 in Debrecen; member of the Debrecen Socialist Revolutionary Committee. In 1957 he was barred from attending university for four years. He worked as an unskilled laborer, teacher and editor, then became director of the county library in Debrecen after 1990. Interview with Zoltán Simon. Debrecen, 1994. Oral History Archive, Budapest, no. 524.

László Szúcs (1934-2008) Worker. In 1956 he was one of the leaders of the workers' committee at the Hajdúság Pharmaceutical Factory in Debrecen. He received a sentence of six years. Throughout the seventies and eighties he led studio classes at the Textiles Department for the College of Applied Arts. Interview with László Szücs László. Budapest, 1992. Oral History Archive, Budapest, no. 383.

László Zeke (1919-1992) Skilled laborer, factory brigade leader. Head of the workers' committee at the Debrecen Tobacco Factory in 1956, one of the leaders of the forum for workers' committees in Debrecen. Sentenced to ten years' incarceration. Upon his release he lived and worked as a factory worker. Interview with László Zeke. Debrecen, 1991. Oral History Archive, Budapest, no. 391.

(Note: All interviews listed above were conducted by the author of this study) 